\title{
Organizational Learning and Financial Performance of Tourism MSMEs in Gowa Regency - South Sulawesi
}

\author{
Ferdinandus Sampe ${ }^{1}$, Lita Limpo ${ }^{2}$ \\ \{ferdisampe@yahoo.com¹, litalimpo3@gmail.com² \\ Accounting Postgraduate, Universitas Atma Jaya Makassar ${ }^{1}$ \\ Management Department FEB, Universitas Atma Jaya Makassar ${ }^{2}$
}

\begin{abstract}
The research was conducted to analyze the relationship between organizational learning and financial performance of tourism service MSMEs in Gowa Regency, South Sulawesi. The results were displayed descriptively before testing the hypothesis using regression analysis. Organizational learning is measured by information acquisition, information dissemination within the organization, information usage, and information storage. Financial performance is measured using indicators perceptions of MSME owners of financial performance. This study shows that the acquisition and storage of information have a positive but not significant influence on financial performance while the dissemination and use of information have a positive and significant effect on MSME financial performance. Overall, organizational learning has a significant effect on financial performance. This finding indicates that owners of MSMEs are not looking for and storing information related to activities to improve financial performance, instead they obtain information and using it effectively in order to improve the MSME financial performance.
\end{abstract}

Keywords: Organizational Learning, Financial Performance, Gowa, and Tourism.

\section{Introduction}

\subsection{Background}

The tourism sector is very crucial to spur Indonesia's economic growth [1]. The Indonesian government has worked hard to develop the industry [2]. In 2019 the Tourism Industry was a one of the main Indonesian sources of income [2]. This confirms the importance of tourism in the Indonesian economy.

The tourism industry is an information-intensive industry [3]. Information-intensive industries require all actors to continue to seek information, find, share, use, and store such information on an ongoing basis [4]. Information seeking, dissemination to organizational members, continuous use and information storage leads to the concept of organizational learning [5]. Thus, so that tourism services businesses can be sustainable, organizational learning concepts must be used.

In addition to information-intensive, the tourism industry also needs to utilize all the potential of the local area as a tourist attraction [6]. Tourism potential that can be used can be in the form of natural attraction, cultural tourist attraction, and man-made tourist attraction [1]. 
The three tourist attractions are strengthened by local wisdom, which is the main tourist attraction [6]. Local wisdom is the foundation of these three tourist attractions.

In Regional Regulation No. 2 of 2015, it is expressly stated that one of the tourism principles of South Sulawesi is local wisdom [2]. The tourism industry in South Sulawesi must be developed according to the values and values of regional life and culture, which are a reflection of local wisdom. The tourism industry, which is supported by local wisdom, will create a unique tourist attraction and does not exist anywhere in the world. This distinctive attraction will create sustainable tourism.

There are interesting facts related to the tourism industry of Gowa Regency. Data from the Tourism Statistics of South Sulawesi (2017) showed that in 2016, domestic tourists' arrival increased sharply from 82,673 people in 2015 to 162,703 and foreign tourists from 15,731 in 2015 to 20,271 in 2016. If presented, the increase was around $1278 \%$ for domestic tourists and $29 \%$ for foreign tourists. On the other hand, hotel occupancy rates in 2016 for star hotels are $40.63 \%$ and non-star $24.85 \%$. Restaurants and restaurants had decreased from 43 units in 2015 to 36 units in 2016. Fixed star hotels are two units, non-star hotels had decreased from 14 in 2015 to 10 units in 2016. The saddest is service providers. Other accommodations dropped dramatically from 17 units in 2015 to the remaining three units in 2016. So, on the one hand, there was a very high increase in the number of tourists, but the hotel occupancy rate was only around 40 percent, and there was even a decrease in the number of accommodation providers [7].

Data from BPS Gowa (2017) shows that in Gowa Regency, there are 185 accommodations, which are businesses that enter MSMEs. The number of accommodations owned by MSMEs indicates that developing tourism in Gowa Regency must develop an investment that grouped into the category of Micro and Small Businesses [7].

The two phenomena of tourism are very interesting to study. First, efforts to develop sustainable tourism are expected to help encourage the development of supporting business units such as hospitality services, accommodation, and improving community welfare. Second, the effort to develop sustainable tourism must involve MSME owners of tourism objects. Efforts to find patterns of utilization of local wisdom as a driver of the benefits of the tourism industry, such as hospitality and accommodation, and optimize the participation of MSMEs in realizing sustainable tourism that benefits all stakeholders.

\subsection{Novelty and Technology Breakthrough}

Makassar's local wisdom as a supporter of the tourism industry will be integrated with the concept of organizational learning and information technology advances in finding, sharing, using, and storing information to be used in decision making that can support the sustainability of tourism industry MSMEs. The use of information technology to search, share, use and store information on local wisdom for making tourism industry development decisions is a new thing offered from the results of this study. This will allow the use of new information technology to transform local wisdom as one of the aspects driving the growth of tourism.

\subsection{Literature Review}

\subsubsection{Organizational learning}

Organizational learning develops from the fact that the operational environment of an organization continues to change so that all members of the organization need to cooperate [8]. Many studies have found that enterprise performance increases with the accumulation of 
information and knowledge [9]. The information and knowledge enabling employees to learn from experience and accept new ideas to be made into policies and action plan to compete [5], [10].

There are many definitions of organizational learning. For example, Edmonstone [11] defined organizational learning as a process to obtain, share, and use knowledge to adapt to changes in the external and internal environment. Organizational learning involves the individual learning process of organizational members, which subsequently accumulates in the organization [12], [13]. The learning process involves emotions and feelings, and in this case, cultural values determine the occurrence of organizational learning [14], [15]. Organizations that give members the freedom to experiment and discover new things can become learning organizations [11]. So the organizational learning process assumes organizational support.

In the tourism MSMEs setting, organizational learning is interpreted as an effort to acquire information about local wisdom and use it to maintain the quality of tourism services, introduce tourist attraction for future interests in providing quality tourism services and enable positive promotion for users.

\subsubsection{Tourism MSME}

Micro, small and medium enterprises (MSME) is regulated in the Regulation of the Republic of Indonesia No.20 of 2008. Article 1 of the regulation defines micro-enterprises as productive businesses owned by individuals and/or individual business entities with less than five permanent employees and assets of at most Rp.50 million excluding land and buildings where businesses have the largest annual sales of Rp.300 million. While, the small-scale enterprise is a productive economic enterprise that is independent, carried out by individuals or business entities that are open subsidiaries or non-subsidiaries owned with 5 to 19 permanent employees with asset values between Rp. 50 and Rp.500 million excluding land and buildings where businesses have annual sales of more than Rp.300 million to a maximum of Rp.2,500,000 million. Also, medium-sized businesses are companies with a net worth of more than Rp.500 million up to a maximum of Rp.100 billion from annual sales of Rp.2.5 billion to a maximum of Rp.50 billion.

\subsubsection{Enterprise Performance}

Enterprise performance relates to factors such as market conditions, development in management theory, technological development, organizational change and restructuring, and government policy [5]. Market conditions are becoming more competitive than in the previous decade [8]. As a result of globalization, enterprise success requires higher levels of performance in the quality of goods and services produced, cost, and speed in innovations [9]. Performance of the tourism industry as a service industry not only assessed in the financial term but also in non-financial performance.

Performance measurement or assessment is a cornerstone for organizations [16]. An increasingly wide spectrum of non-financial measures is now being applied within companies, which can be categorized by the terms "hard" and "soft". The "hard" spectrum includes measures such as financial performance (profit, sales), lead-time, and on-time delivery, which are can easily be quantified and require objective input. On the other hand, "soft" issues such as consumer satisfaction and other stakeholder satisfaction are more difficult to measure as a consequence of the subjective perception of performance. To have a "true" reflection of enterprise performance, both hard and soft measures, should be used.

Multi-dimensional performance measures based on self-reported ratings were developed for this research to measure SEs performance [16]. Owner-managers were asked to indicate 
their perception of firm performance relative to expectations on each of the terms related to sales, profits, product quality, and satisfaction of customers, owner-managers, and stakeholders. In specific terms, performance in this research will be assessed using profit increases in the two years, product quality increase in the last two years, customers/consumers' satisfaction with enterprise products, costumers/consumers satisfaction expressed, advisor satisfaction on enterprise performance, owner satisfaction with enterprise contribution to family welfare, recent and the last two years comparison of enterprise performance.

\subsubsection{Previous studies}

A number of previous studies related to aspects of organizational learning in MSMEs have been carried out [5],[9],[13],[14],[17],[18],[19],[20],[21]. All studies have contributed one or more aspects of knowledge to find, share, use, and store information on MSMEs.

Olympia Kyriakidou and Julie Gore (2005) interviewed 89 MSME owners in the UK and found that MSMEs operating in the tourism industry use cultural values as a driver for organizational learning. Furthermore, they found that MSMEs in the tourism industry are building the future by establishing excellence-based missions and strategies and sustainable learning processes [14].

Erick T. Byrd [22] in his research on MSMEs in New York, the United States found that the culture of knowledge sharing and collaboration among organizational members helped the organization to achieve its strategic goals. Organizational learning has a positive influence on corporate sustainability.

Mohammad Hossein Imani Khoshkhoo and Zahra Nadalipour [5] examined organizational learning in MSMEs in Iran. He found that the quality of the acquisition, distribution, use, and storage of MSME organizations determines organizational performance. MSMEs that are painstakingly implementing organizational learning have better performance. Continuous learning processes also have positive implications for improving organizational performance.

Research in Indonesia has been carried out by Ridwan and his friends. Ridwan, Manda, Putra, Usman, Muhammad, Tang, Yusni, Ikhwan, Siregar, Thamrin [17] examined the community around the Kampar River, Riau Province. They found that ecosystem sustainability can encourage the sustainability of the tourism industry. The social and cultural dimensions and legal aspects play an important role in ensuring the sustainability of the tourism industry. In his study, Sample [16] found that organizational learning activities have been carried out in SME business practices and that organizational learning has a real influence on improving enterprise performance. Also, it was found that organizational culture plays a major role in creating organizational learning [16].

Organizational learning and enterprise performance has been investigated by many previous researchers who found a positive association between organizational learning and organizational performance [23],[24],[25]. Bontis, Crossan, and Hullan [26] found that individual-level learning, group-level learning, and organizational learning have a valid direct association with organizational performance. 


\section{Method}

\subsection{Location}

The location for data collection was Gowa Regency, South Sulawesi, Indonesia. There are 150 hotels, inns, and guesthouses the Regency. Using convenience sampling, 55 of the accommodations were selected.

\subsection{Data collection method}

The survey was employed to collect data. Questionnaires were hand-delivered to hotel and inn owner/managers from June $1^{\text {st }}$ to August $2^{\text {nd }}, 2019$. As many as 70 questionnaires were distributed, 55 were completed and used in the data analysis.

\subsection{Data Analysis}

\subsubsection{Descriptive analysis}

Descriptive analysis was used to describe the research finding using mean and standard deviation. Prior to the organizational learning and enterprise performance indicators, description, gender, age, education, and tenure were presented.

\subsubsection{Regression analysis}

Regression analysis was applied to assess significance of organizational learning influence on enterprise performance as well as to test the research hypothesis.

\section{Result and Discussion}

Results are presented into two main criteria, namely, respondents' background and descriptive statistics of the finding.

\subsection{Respondents characteristics}

Respondent characteristics were provided in terms of gender, age, education, and tenure.

\subsubsection{Gender}

Most of the respondents were male. Male comprised 41 or 74.5 percent of respondents, while the rest 14 or 25.5 percent are female.

\subsubsection{Age}

Respondents' age was divided into four groups, namely between 20 to 29 years old, 30 to 39,40 to 49 , and fifty and above. Details of respondents' age are presented in table 1 below.

Table 1. Age

\begin{tabular}{ccc}
\hline Age & Frequency & Valid Percent \\
\hline 20 - 29 Year & 12.7 & 12.7 \\
$30-39$ Year & 67.3 & 80.0 \\
40 - 49 Year & 16.4 & 96.4 \\
$>$ 50 Year & 3.6 & 100.0 \\
\hline
\end{tabular}




\begin{tabular}{cc}
\hline & \multicolumn{1}{c}{100.0} \\
\hline Source: Primary data processed using SPSS 21, 2018.
\end{tabular}

As can be seen, most respondents were between 30 to 39 .

\subsubsection{Education}

Respondents were divided into three groups, namely senior high school, diploma, and bachelor. The respondent's education is presented in table 2 .

Table 2. Education

\begin{tabular}{lc}
\hline & Frequency \\
\hline Senior high school & 13 \\
Diploma & 9 \\
Bachelor & 33 \\
Total & 55 \\
\hline Source: Primary data processed using SPSS 21, 2018.
\end{tabular}

As can be seen in table 3, most respondents already have bachelor degree.

\subsubsection{Tenure}

Tenure was grouped into four groups for less than two years, 2 to 6 years, 6 to 10 years, and more than ten years. The respondent's tenure is presented in table 3 .

Table 3. Tenure

\begin{tabular}{cccc}
\hline Tenure & Frequency & Percent & Valid Percent \\
\hline$<2$ Year & 2 & 3.6 & 3.6 \\
2,1 - 6 Year & 23 & 41.8 & 41.8 \\
6, - 10 Year & 20 & 36.4 & 36.4 \\
$>$ 10 Yaer & 10 & 18.2 & 18.2 \\
Total & 55 & 100.0 & 100.0 \\
\hline
\end{tabular}

Source: Data collected for the study

As can be seen in table 3, respondents' tenure mostly between 2 to 6 years.

\subsection{Descriptive Analysis}

\subsubsection{Organizational learning}

Organizational learning practice was measured by 14 indicators. The descriptive results are presented in table 4.

Table 4. Organizational learning

\begin{tabular}{llcc}
\hline No & \multicolumn{1}{c}{ Description } & $\begin{array}{c}\text { Average } \\
\text { Score }\end{array}$ & $\begin{array}{c}\text { Standard } \\
\text { deviation }\end{array}$ \\
\hline 1 & thinking from a global perspective & 4.18 & 0.611 \\
2 & support each other to learn & 4.11 & 0.712 \\
3 & spending time building trust & 4.18 & 0.722 \\
4 & Learning together & 4.05 & 0.780 \\
5 & rewarding for learning & 3.91 & 0.616 \\
6 & free to initiate changes & 3.85 & 0.731 \\
\hline
\end{tabular}




\begin{tabular}{llll}
\hline 7 & Calculate risk-taking & 3.73 & 0.804 \\
8 & adapt operational goals as needed & 3.89 & 0.712 \\
9 & building alignment of vision across structural levels & 2.76 & 0.881 \\
10 & sharing similar visions and missions & 3.00 & 0.923 \\
11 & Sharing similar objectives & 3.45 & 0.603 \\
12 & getting necessary information quickly and easily & 3.45 & 0.765 \\
13 & up-to-date database of employee expertise & 3.44 & 0.877 \\
14 & I love to share knowledge & 3.27 & 0.891 \\
\hline
\end{tabular}

Source: Data analysis

A 5 point Likert scale was the basis for reporting respondent opinions/results. Indicators 1. 2. 3 and 4 have an average score of more than 4 indicates the high intensity of acquiring information from external sources. In general. All other indicators reveal a medium level of organizational learning practices. Only one indicator, namely the activity of building alignment of vision across different structural levels, indicates a low level of owner/manager to share their vision to all levels of enterprise structure.

\subsubsection{MSMES Performance}

MSME performance, as presented in table 6. indicates that SE owner-managers perceive that their enterprise performance was "good". Mean scores for each of the eight assessment items were higher than 3 , with only item employes were satisfied with enterprise contribution for their family welfare indicates low performance. The complete descriptive results of response on MSME are presented in table 5.

Table 5. MSME Performance

\begin{tabular}{llcc}
\hline No & \multicolumn{1}{c}{ Description } & $\begin{array}{c}\text { Average } \\
\text { Score }\end{array}$ & $\begin{array}{c}\text { Standard } \\
\text { deviation }\end{array}$ \\
\hline 1 & enterprise sales increased in the last two years. & 4.28 & 0.758 \\
3 & Service quality increased in the last two years & 3.98 & 0.450 \\
4 & customers/consumers satisfied with the enterprise service & 4.09 & 0.58 \\
5 & Less customer/guest complaints in the last two years & 4.13 & 0.681 \\
6 & Guest satisfied our enterprise performance & 3.92 & 0.731 \\
7 & Employes were satisfied with enterprise contribution for & 3.68 & 0.913 \\
8 & their family welfare & 3.83 & 0.610 \\
\hline
\end{tabular}

The mean from the Likert scale for all responses and all items was more than 3.5, indicating that on a 5 point scale. There was strong support for stating that owner-manager opinions on the performance of their enterprises were good.

\subsubsection{Influence of organizational learning on MSME performance}

The influence of organizational learning on MSME performance was assessed using regression analysis, which is presented in table 6 . 
Table 6. Organizational learning regression on MSME performance

\begin{tabular}{|c|c|c|c|c|c|}
\hline \multicolumn{6}{|c|}{ Model Summary } \\
\hline Model & $\mathrm{R}$ & R Square & Adjusted R Square & \multicolumn{2}{|c|}{ Std. The error of the Estimate } \\
\hline 1 & 0.288 & 0.083 & 0.078 & \multicolumn{2}{|c|}{1.2748} \\
\hline \multicolumn{6}{|c|}{ ANOVA } \\
\hline Model & $\begin{array}{l}\text { Sum of } \\
\text { Squares }\end{array}$ & df & Mean of square & $\mathrm{F}$ & Sig \\
\hline $\begin{array}{l}1 \text { Regression } \\
\text { Residual } \\
\text { Total } \\
\end{array}$ & $\begin{array}{c}27.970 \\
310.399 \\
338.369 \\
\end{array}$ & $\begin{array}{l}191 \\
192 \\
\end{array}$ & $\begin{array}{c}27.970 \\
1.625\end{array}$ & 17.211 & 0.000 \\
\hline \multicolumn{6}{|c|}{ Coefficient } \\
\hline Model & Unstandard & ed coefficient & $\begin{array}{c}\text { Standardized } \\
\text { coefficient }\end{array}$ & $\mathrm{t}$ & Sig \\
\hline & $\mathrm{B}$ & Std Error & beta & & \\
\hline $\begin{array}{l}1 \\
\text { Constant }\end{array}$ & $\begin{array}{l}6.766 \\
0.171\end{array}$ & $\begin{array}{l}0.158 \\
0.041\end{array}$ & 0.288 & $\begin{array}{c}42.916 \\
4.149\end{array}$ & $\begin{array}{l}0.000 \\
0.000\end{array}$ \\
\hline \multicolumn{6}{|c|}{$\begin{array}{l}\text { perform } \\
\text { Where : Predictor: (Constant). MSME Perform - organizational learning } \\
\text { Source: developed from data analysis }\end{array}$} \\
\hline
\end{tabular}

As can be seen in table 7., standardized coefficient $b$ for MSME of 0.288 indicated that a difference of one standard deviation in organizational learning practices is predicted to cause a difference of 0.288 standard deviations in performance. If the score of formal planning activities were increased one unit. It would be expected that performance would change by 0.288 units.

Also, as can be seen in table 7. 8.3\% $\left(\mathrm{R}^{2}\right)$ of variation of the independent variable can be explained by the model [27]. F value of 17.211 serves to test how well the regression model fits the data, and the probability associated with the F statistic is small $(0.000)$, so there is a positive and significant relationship between organizational learning practices and MSME performance.

\section{Conclusion Contribution and Limitations}

\subsection{Conclusion}

Two conclusions can be drawn from the study :

1. This research was intended to examine the existence of organizational learning practices on MSME in the tourism industry. The research findings show that organizational learning practices in MSME surveyed were generally applied at a medium level.

2. Organizational learning practices are significantly related to the performance of tourism MSME. Organizational learning affects organizational performance by promoting trust among employees in acquiring, disseminating, exploiting, and storing knowledge. MSME 
organizational learning practices of allowing employees to think comprehensively, building trust among employees rewarding employees for learning, and maintaining an upto-date database of employee skills were positively related to the organizational product sale, employee, and customer happiness and the general successfulness of the organization.

\subsection{Contribution}

Two main contributions of the study are :

1. Theoretically, the study provides additional evidence that organizational learning practices influence enterprise performance. Continuous knowledge acquisition, knowledge dissemination, knowledge usage, and knowledge storage would lead to better enterprise performance.

2. Practically. in assisting tourism MSME in order to increase their enterprise performance, the government should consider not only financial and marketing aspects of management but also how the enterprises maximize all aspects of information acquisition, dissemination, usage, and storage.

\subsection{Limitations}

This research had two main limitations:

1. This study was conducted in the South Sulawesi Province of Indonesia, and the outcomes may not reflect the perception of owner-managers in other Provinces. Focusing on Indonesian MSME that operates in South Sulawesi, while valid from a research design perspective, may affect the general application of the results. Consequently, careful consideration needs to be given to using the findings of this research, and further research is encouraged for verification in specific regions.

2. Data for this study was restricted to organizational learning practices for MSME performance. It may not be possible. Therefore, to generalize from the conclusions of this study and apply the conclusions to other areas of enterprise activities.

\section{References}

[1] D. Bidang. P. Destinasi. and K. Pariwisata. "'kebijakan pembangunan pariwisata nasional di sulawesi." no. April. (2018)

[2] B. Perencanaan. D. A. N. Keuangan. and S. Kementerian. "Laporan Kinerja Kementerian Pariwisata Tahun 2016." (2016)

[3] Yenidoğan, Ö., and Şencan, H.: "The Effect of Organizatonal Learning on Organizational Commitment in Accommodation Sector.” Int. J. Commer. Financ.. vol. 3. no. 1. pp. 27-40. (2017)

[4] Mariani, M., Baggio, R., Fuchs, M., and Höepken, W.: "Business intelligence and big data in hospitality and tourism: a systematic literature review." Int. J. Contemp. Hosp. Manag (2018)

[5] Khoshkhoo, M. H. I., and Nadalipour, Z.: "Tourism SMEs and organizational learning in a competitive environment." Learn. Organ (2016)

[6] Cheng, E. Ma. M,. and Hsiao, A.: "Sentiment analysis-a review and agenda for future research in hospitality contexts.” Int. J. Contemp. Hosp. Manag (2018)

[7] Gowa, B. P. S. K.: “Kabupaten Gowa dalam Angka 2017.” Daradjat Zakiah. Ilmi Jiwa Agama. (2017)

[8] Matthews, R. L., MacCarthy, B. L., and Braziotis, C.: "Organisational learning in SMEs: a process improvement perspective.” Int. J. Oper. Prod. Manag (2017)

[9] Hoppstadius, F., and Möller, C.: "You have to try being a role model.” Eur. J. Tour. Res. Vol. 
20. vol. 20. pp. 28-45 (2018)

[10] Valdés, R. M. T., Álvarez, C. L., Spila, J. C., and Santa Soriano, A.: "Relational university. learning and entrepreneurship ecosystems for sustainable tourism." J. Sci. Technol. Policy Manag. (2018)

[11] Edmonstone, J: "Organisational learning." in Why Hospitals Fail. Springer pp. 129-135 (2017)

[12] Nugroho, M. A.: "The effects of collaborative cultures and knowledge sharing on organizational learning." J. Organ. Chang. Manag. (2018)

[13] Úbeda-García, M., Claver-Cortés, E., Marco-Lajara, B, García-Lillo, F., and Zaragoza-Sáez, P. C.: "Continuous innovation in the hotel industry." Int. J. Contemp. Hosp. Manag. (2018)

[14] Kyriakidou, O., and Gore, J.: "Learning by example." Benchmarking An Int. J.. 2005.

[15] Kraleva, N.: "Learning organizations: Prerequisite for successful tourism organizations." UTMS J. Econ. vol. 2. no. 1. pp. 77-82 (2011)

[16] Sampe. F.: "The influence of organizational learning on performance in Indonesian SMEs." (2012)

[17] Putra, R. M., Tang, U. M., Siregar, Y. I., and Thamrin, T.: "Sustainability analysis of the management of Lake in Buluh Cina Village. Indonesia." Smart Sustain. Built Environ.. (2018)

[18] Castro-Spila, J., orres, R., Lorenzo C., and Santa. A.: "Social innovation and sustainable tourism lab: an explorative model." High. Educ. Ski. Work. Learn. (2018)

[19] Hartman. S.: "Towards adaptive tourism areas: using fitness landscapes for managing and futureproofing tourism area development." J. Tour. Futur (2018)

[20] Heidari, A., Yazdani, H.R., Saghafi, F., and Jalilvand, M. R.: "A systematic mapping study on tourism business networks." Eur. Bus. Rev. (2018)

[21] Jones, A., and Navarro, C.: "Events and the blue economy." Int. J. Event Festiv. Manag. (2018)

[22] Byrd, E. T.: "Stakeholders in sustainable tourism development and their roles: applying stakeholder theory to sustainable tourism development." Tour. Rev. (2007)

[23] Montes, F. J. L., Moreno, A. R. and Morales, V. G.: "Influence of support leadership and teamwork cohesion on organizational learning. innovation and performance: an empirical examination." Technovation. vol. 25. no. 10. pp. 1159-1172 (2005)

[24] Garcia-Morales., V. J., Lloréns-Montes, F. J., and Verdu-Jover. A. J.: "Influence of personal mastery on organizational performance through organizational learning and innovation in large firms and SMEs." Technovation. vol. 27. no. 9. pp. 547-568 (2007)

[25] Jyothibabu C., Pradhan. B. B., and Farooq, A.: "Organisational learning and performance-an empirical study." Int. J. Learn. Chang.. vol. 5. no. 1. pp. 68-83 (2011)

[26] Bontis, N., Crossan, M. M., and Hulland. J.: "Managing an organizational learning system by aligning stocks and flows.” J. Manag. Stud.. vol. 39. no. 4. pp. 437-469 (2002)

[27] Norušis, M. J.: Guide to data analysis: SPSS 10.0. Prentice Hall (2000) 